\title{
THE DYNAMICS OF THE NURSING PROCESS
}

\author{
T.G. MASHABA \\ DNE, DNA, BA(Cur)
}

\section{OPSOMMING}

Die verpleegproses as wetenskaplike metode vir die beplanning en uitvoer van verpleegsorg word bespreek. Dit is ' $n$ dinamiese proses aangesien dit by die behoeftes van individuele pasiënte en die spesifieke stiuasie aangepas kan word. Die stappe in die verpleegproses is behoeftebepaling, beplanning, implementering, evaluering en die hou van rekords.

\section{INTRODUCTION}

$\mathbf{T}^{\mathrm{H}}$ HE nursing process is a scientific method of approaching and planning the nursing care of the patient. It is an ongoing process and has a different meaning for each patient at different stages of his illness. It also varies from one nurse to another and at different levels of a nurse's professional maturity and in different nursing situations.

Among nursing writers who define the nursing process, Yura and Walsh see it as

- . an orderly, systematic manner of determining the client's problems, making plans to solve them, initidting the plan or assigning others to implement it, and evaluating the extent to which the plan was effective in resolving the problems identified. ${ }^{1}$

In practising the nursing process one focuses attention more on the individual patient and his problems than on the features of his disease. Therefore, this approach is a patientcentred, comprehensive activity which entails definite logical steps.

\section{THE HISTORICAL BACK- GROUND}

In the very early days nursing, as a vocation, was practised by men and women who came forward voluntarily to minister to the sick and suffering. Through their concern for other people they did their best to meet the basic human needs of the sick. The quality of this type of nursing depended on the judgement of experienced helpers.

In the days of Florence Nightingale (1820-1910) nursing took on a definite structure. Nightingale introduced reforms and set admirable goals. She strove to provide the best care for her patients and succeeded in giving nursing the respectability it deserved. She established a foundation from which nursing continued to evolve up to the present date.

After Nightingale's era there was a period of lag in nursing until the World War II period which was characterised by the accumulation of knowledge. The knowledge included advances in medicine which prompted changes that spilled over to nursing. Among the innovations was the multi-disciplinary team approach to patient care.

This approach made it necessary to define the role of each member of the team. Nurses became concerned about defining and retaining that which is essentially nursing and establishing nursing as a profession. Definitions, concepts and theories of nursing began to appear with increasing frequency by writers such as Olivia Gowan, Dorothy Johnson, Virginia Henderson and others.
The term nursing process was first mentioned in the 1950's. Early in the 1960's it was defined but not immediately accepted. The concept nursing process only gained acceptability recently after different nurses and nursing committees had presented their versions.

As a method of nursing the nursing process can only be described adequately against the concept or within the context of nursing.

\section{THE CONCEPT NURSING}

Many attempts have been made to pin-point, extract and analyse the core of nursing. Henderson's definition is appropriate. She explains nursing as

... assist(ing) the individual, sick or well, in the performance of those activities contributing to health, or recovery, or to a peaceful death, that he would perform unaided if he had the necessary strength, will or knowledge ...2

This means that nursing is a patient-centred activity performed by the nurse to help the individual patient until he attains full recovery and normal functioning or until he dies peacefully. If nursing activity is to be adapted to the individual patient; his particular illness and his age; his deteriorating or improving condition; then it cannot be rigid, stereotyped and static. It has to be 
dynamic and flexible. These progressive and adaptable nursing activities flow from what nurses framed and called the nursing process.

\section{DYNAMISM IN NURSING}

The propelling force of the nursing process lies in the changes in the many related facets of nursing situations and the interwoven needs of individual patients. This on-going feature of the nursing process is aptly described by Burger and Newton in their definition:

...the (nursing) process is always dynamic being affected by the needs of the person, the circumstances affecting the needs, and the situation in which it has to be applied. It has emotional, physical, medical and social aspects. It is for the person, with the person, to the person where he finds himself. ${ }^{3}$

The nursing process operates whenever there is a patient and a nurse, be it in a home situation, an institutional setting or an extrainstitutional locality. It attains the preventive dimension if necessary, the promotive dimension if the health of the individual needs to be improved; a curative dimension in a therapeutic context, and a rehabilitative dimension if maximum functioning is to be restored.

According to Henderson's definition of nursing the goals of nursing are health, recovery or a peaceful death. Therefore, the nursing process applied to an acutely or a critically ill patient will have a different content to that applied to a well client whose health must be promoted. It will again take a different shape to make it possible to meet the needs of a dying patient if he is to die peacefully.

In implementing the nursing process the nurse should capture and preserve the essence of nursing by showing genuine interest, empathy and understanding of the patient's predicament. She should show concern for her patient's needs, exercise care in such a way that the patient feels wanted; do all in her power to help cure the patient's illness or disease; and co-ordinate her activities with those of her colleagues. The nursing process should be so comprehensive that, as Sister Gowan puts it, it means

involving the total patient; promoting spiritual. mental and physical health; stressing health education and health preservation. ministering to the sick. caring for the patient's environment; giving health service to the family, the community and the individual. ${ }^{4}$

This means that the nursing process takes care of the total man in his environment.

The holistic approach balances on supportive functional areas. The area of nursing education provides the pre-required knowledge to enable the nurse practitioner to understand his patient/client: how and why he behaves in a particular manner, what to do for him and when to do it. The area of nursing administration provides the manpower and material requirements conducive to applying the nursing process. Nursing research is a propelling force towards improved and effective nursing.

\section{STEPS IN THE NURSING PROCESS}

There are definite logical stages or elements contained in any nursing situation. South African writers identify five elements whereas American writers such as Marriner, Yura and Walsh, Watson and others describe only four elements.

\section{Step 1: The patient's needs - assessment}

This step is regarded by American writers as the assessment. It consists of identifying and defining the patient's problem. At this stage the nurse collects all the relevant data concerning the patient's condition. This information is obtained from the patient, his relatives and his community. Secondary sources such as medical and social records, nurse's rounds, reports during the change of shift are helpful. It is ideal to devise a format, such as a questionnaire or checklist, that is flexible and can be adapted to the variety of the patient's problems. Using this, the nurse interviews the patient and his relatives through various communication techniques, such as open-ended questions, and examinations. Thereafter she makes accurate observations, using all her senses plus the variety of tools available.

To enable the nurse to assess the patient effectively a good knowledge of biological, natural and social sciences is necessary. She should be clear as to what is pathological and what is normal or what the model of wellness is. ${ }^{5}$ She bases her assessment on basic human needs. For that she could use as a guide one of the theoretical models such as Maslow's hierachy of needs. According to Maslow man's needs are physiological needs including the need for food, oxygen, elimination, rest, water and physical activity which must be satisfied; the need for safety and security; the need for love and belonging; and finally the need for self-esteem. These needs should be satisfied in the order given, for they stand in the order of priority.

The nurse collects and analyses all the available information about the patient while focussing on the preventive, curative, promotive and rehabilitative aspects of patient care. The information is sorted, analysed and recorded. Some hospitals have designed the nursing history form for this purpose.

The stage of assessment begins with taking the nursing history and ends with making the nursing diagnosis - the nurse spells out the problem of the patient and is ready to embark on a plan of action.

\section{Step 2: Reaction by the nurse - planning}

Formulating a plan to solve the patient's problems needs thought and improves with experience. A plan should not be a rigid framework for people to fit into. It should be a set of guidelines which are flexible and adaptable.

Ideally, all those who will be participating in the nursing care, including the patient and his relatives, should be involved when designing the care plan. Having identified the problem, and drawn inferences, the nurse takes decisions as to what to do, where, when, how and why it is to be done, and by whom it is going to be done. In consultation with the patient and significant others, the priorities are set. The extent to which the patient is involved depends on his mental state, his level of intelligence and his physical condition. Lifethreatening issues such as an obstructed airway and impaired circulation should receive highest priority. Priorities can then be assigned ac- 
cording to Maslow's hierachy of physiological needs.

Immediate, proximate and ultimate goals should be set. The immediate goal may be solving the major problems such as eliminating pain, relaxing a spasm or putting a limb in the best possible position for healing to take place. The intermediate goals may be prevention of complications such as contractures, sepsis and the spread of infection. The long-term goal may be a maximal degree of independent functioning, regaining and maintaining good health, preventing a relapse or recurrence of the disease.

The planning proceeds to deciding what actions should be taken to satisfy the patient's needs and to attain the goals and which and how many people are needed to execute the plan. A well-developed referral system is needed to assign different tasks to appropriate personnel such as social problems to the social worker, physical exercises to the physiotherapist, speech problems to the speech therapist; legal matters to the lawyer; and spiritual problems to the minister of religion.

The means and methods of doing things to meet the needs and reach the goals are specified. The planner takes into account the time factor, supplies and human and material resources. The planners of the nursing process should avoid making a plan that will fall into step with the established traditions. The plan should be realistic, practical and appropriate to the particular individual, depending on the patient's age, sex, life-style, level of education, socioeconomic status and cultural background.

The plan is then written reflecting, in addition to the above, the patient's abilities, preferences and limitations. Copies of the plan should be distributed among all who will take part in implementing it.

The planning step thus begins with the nursing diagnosis and ends with the team getting ready for nursing action.

\section{Step 3: Intervention by the nurse - implementation}

The plan which is a blueprint for action is then executed. Whether the plan will succeed or not depends largely on the nurse's intellectual and technical abilities as well as good interpersonal relations and the extent of therapeutic use of self. Implementation starts when the patient is admitted to his bed and ends when the patient is restored to his pre-illness condition within his family, and his community. It can also end when the patient's body is removed after death.

The unfolding of the nursing plan consists of the nurse carrying out the doctor's orders, undertaking nursing actions and referring patients to other agencies or other departments, as necessary. The nurse maintains the personal and the environmental hygiene of the patient. She gives treatments, drugs and medications. She does tests and nursing procedures, observes, records and reports on the patient; communicates and interacts with the patient, his relatives and other members of the health team; provides health education to the patient and his relatives and re-trains the patient by helping him to help himself.

A well designed plan will have a system of referral. Referrals afford continuity of patient care. They may be written or verbal, and they help the patient to regain the highest degree of wellness. Referrals can be made to a social agency, a clinic, a nursing home, a special home, a specialist, a public health agency, a rehabilitative centre or to another department in the same hospital.

Implementation of a plan means initiating care and facilitating continuity of care from one department or agency to another. It is the process whereby immediate, proximate and ultimate goals are reached. It may give rise to another plan. In all nursing situations the reaction and the response of the patient are vital factors in assessing whether goals are being attained.

\section{Step 4: Assessment by the nurse - evaluation}

This step involves pausing and looking back at what has been done and at responses that have occurred since the initial step. The purpose is to establish whether the objectives are being achieved, whether the plan needs to be amended or to be aban- doned and started all over again. It is a mental step in which the nurse stands apart from the team to see if it is functioning as expected and if, and to what extent the patient is benefiting. Yura and Walsh maintain that: evaluation means to appraise the client's behavioural changes due to the actions of the nurse."6

The nurse evaluates in terms of the patient's progress towards health, to see whether the patient is recovering as was anticipated. The patient's behaviour and condition at the time of evaluation should compare favourably with that which was described in the nursing care plan. The evaluation can be daily, weekly or it can be done before the patient is discharged. The nursing audit, a formal systematic written appraisal of progress, is a useful tool. It can be used for evaluating the patient's progress and the quality of care. It helps to improve patient care by unveiling serious problems and significant weaknesses. Through the nursing audit it is possible to detect if nurses know what they are doing, when, where, why and how they are doing it.

The activity of evaluation should also include self-evaluation. Here, the nurse does some introspection and self-quizzing to take stock of her own performance, find her strong points and detect her weaknesses and decide on how she can improve.

Evaluation of the personnel participating in the nursing process is vital. A comparison is made between the performance that is observable at the time and the desired performance. The reason for the discrepancy is sought and if possible eliminated.

All aspects of evaluation should have the patient as the central figure. The patient should therefore be involved, depending on his mental and physical condition. Useful information can be gained from his family and relatives if they are available.

A number of evaluative devices can be used, such as the nursing conference, nursing audit, anecdotal record, checklist, critical incident and rating. The choice of evaluation tool should be made at the planning stage of the nursing process. Deciding on which instrument to use depends on whether the particular tool measures what it is supposed to measure, in other words whether it is 
valid. The evaluator should ask such questions as: Are the patient's needs being met? Are the goals realistic? Are they being attained? Are the best methods being employed? Is manpower and material appropriate and enough? What is lacking? What new goals should be set? What better approaches can be used? How does the patient feel about all this? Similar and many other questions will ensure collection of relevant and meaningful information.

Having been collected the information is analysed and synthesised and a picture emerges. It becomes apparent whether the plan should be amended, adapted or started afresh, or whether the implementation should continue. Evaluation not only improves patient care, but is also an educational exercise for the nurse.

\section{Step 5: Recording of the four steps}

In South Africa recording is regarded as the last step in the nursing process. American writers see this as an activity that is part of each and every step and therefore not a separate entity. The recording step entails writing and preserving everything, from the patient's personal particulars to his property, treatment, tests, movements, responses, progress, complications, condition, admission, discharges, death, operations up to his food and an account of how and when the nurse featured in all these.

The nurse is obliged to keep accurate records of all she does as these records are legal documents. Safety of the patient's person and property is preserved through accurately kept records. The nurse must account for her actions by presenting written proof of what care she provided for a patient, accountability is an important element in nursing. By virtue of her professional status and proximity to the patient the nurse is entrusted with the patient's life, person and property. Accurately kept records will help her out in case she is accused of malpractice. Through recording, the continuity of patient care is ensured for instance in cases when the staff changes shifts or departments or when the patient changes departments through transfer.

\section{HOW THE NURSING PRO- CESS IS F ACILITATED}

Lois Knowles (1966) described a model of activities which a nurse should master and use to enable her to facilitate the nursing process. She called them the five D's. ${ }^{9}$

“ $D$-Discover. The nurse acquires knowledge or information she did not know previously. This information contributes to better patient care.

$D$ - Delve. The nurse digs for information from a variety of sources to provide data about the client, which will assist her in providing for care.

$D$-Decide. The nurse plans the approach to use in providing patient care. She elects to embark upon a course that is most appropriate for the particular patient.

$D$ - Discriminate. The nurse distinguishes priorities and reactions by discerning differences in problems and in the needs experienced by the patients/clients. This amounts to sorting out what to do first and what to do next, what is the expected response, what is essential, what is relevant, what is urgent and what is not.

$D$ - Do. The nurse activates the plan that has been developed by performing the functions and duties. This means taking definite action to get the plan implemented."

The five D's can be used by the nurse to effect the nursing process systematically and to plan realistically. These actions cut across all the steps of the nursing process. The planning can also be approached by utilising Kipling's six honest serving men: who, why, what, where, how and when.

\section{OTHER ASPECTS OF THE NURSE'S ROLE}

In an attempt to be thorough in rendering this individualised care the nurse usually finds herself unable to meet the many demands and needs of all het patients. Because of modern machinery, tools, equipment and pre-packed supplies the nurse is able to give good care to many patients within a reasonable period of time. Technological advances have added a new dimension to nursing practice and removed certain limitations to patient care.

The nurse practitioner should al- ways aim at accuracy and punctuality. This must be reflected in her historytaking, observations, tests, examinations, recordings, reports, planning, interventions and evaluations.

In executing the nursing process the nurse functions dependently, interdependently and independently. Independently she makes findings, draws conclusions and takes decisions as guided by her training and professional experience. Her functioning depends on the co-operation and condition of the patient and on the fact that she is the extended arm of the medical practitioner. Although she spearheads the working of the health team, like a cog in the wheel, she functions interdependently in cooperation and in consultation with the other members of the total health team.

The nursing process accommodates the cultural component. The nurse must be familiar with practices that are taboo in the culture of her patient and those that are norms of his society. Her health guidance and health education will be effective and meaningful only if it is in keeping with what is acceptable in her patient's culture. Catering for the human element gives colour and life to the nursing process, and, therefore, cannot be over emphasised.

If the nursing process is to be meaningful to its recipient the nurse must reach out across the ethnic, religious, political and cultural barriers to demonstrate genuine concern for and involvement with her patient.

For the best results the nurse should deliberately seek to win the patient's confidence. It is the small, apparently insignificant gestures that foster a healthy relationship between the distressed, apprehensive patient and the unknown stranger - the nurse. On the part of the nurse, willingness to help; thoughtfulness anticipation of the patient's needs; the readiness to listen and to answer questions in a patient, kindly, nonjudgemental manner; and the light touch of the nurse's hand will go a long way towards making the patient's life easier. If the nurse can be more personal and address the patient by his name, show respect for his personal preferences, orientate the patient to his environment, explain what will happen and what is 
expected of him - not only will the patient's tension be relieved, but his anxiety dispelled and the way will be paved to either a speedy recovery or to a peaceful death.

\section{CONCLUSION}

In the light of the foregoing it is apparent that the nursing process is one of the most valuable scientific methods of effecting nursing practice. It is dynamic in nature - it's five steps follow each other logically and interlock like the rings of a chain. The process takes it's form from the particular patient, the nature of the environment and the particular nurse. It can take on colour and gain depth depending on the multitude of factors and forces that have a bearing on the nursing situation. To make a success of the nursing process takes a seasoned nurse who is willing to do some homework and hard work.

Bibliography

Yura. H: Walsh. M.B. The Nursing Process. AppeltonCentury Crofts. New York. 1973. p23.

2. Henderson. V. The Nature of Nursing. Macmillan Company. New York. 1966. p67.
3. Burger, A; Newton, G. Noles on Thearv and Practice of Nursing.

Yura, H.: Walsh, M. B. The Nursing Process, AppletonCentury Crofts. New York. 1973. pl1

. ibid $\mathrm{p} 82$.

6. ibid p. 30

Brown. E.L. Nursing Recionsidered. A siudy of change Lippincot Company. Philadelphia. 1971

Heidgerken. LE. The Imuprovement of Nursing Through Heidgerken, L.E. The lmisurem Reserich. Catholic Universily or America Press. 1959 Company. St. Louis. 1979, p21.

10. Schreiber, L.A. The Comprehensive Assessment System The South African Nursing Journal Vol 44 No. 8 August 1977

1. Searle. C. 'n Suid-Afrikaanse V'erplegingscredo. Universiteit van Pretoria Pretoria. 1969

2. Wat son, J.E. Medical-Surgical Nursing. W. B. Saunders. London. 1972

3. Strauss S.A. Aspects of Legislation for Health Service Personnel. King Edward VIl Trust. Cape Town. 1979

14. Nursing Administration 1. Guide 1. University of South Africa. Pretoria. 1975.

\title{
PROGRAM FOR THE NURSING SESSIONS TO BE PRESENTED AT THE SOUTH AFRICAN MULTI-DICIPLINARY MEDICAL CONGRESS
}

\author{
6 - 12 JULY 1981
}

7 July 1981

Subject: Die Ontwikkeling van Nefrologie as Verpleegspesialiteitsrigting

Chairman: Prof W.J. Kotzé

Speaker: Mrs H.H.M. Uys

Speakers: Prof C. Searle

Prof A.D.B. van den Berg

Prof J.N. de Klerk

9 July 1981

Subject: Advanced Midwifery and Neonatal Care

Chairman: Mrs B. Stander

Speaker: Mrs E.M. Maclure

\section{July 1981}

Panel Discussion

Subject: The Multi-Disciplinary Team in Private Medical Practice

Chairman: Dr E.W. Turton
10 July 1981

Subject: Cardiac Rehabilitation

Chairman: Mrs D. Harrington

Speaker: Mrs D. Nieman
Die Departement van Verpleegkunde aan die Universiteit van Port Elizabeth beoog om 'n multi-nasionale verpleegsimposium op die kampus van UPE op 24 en 25 September 1981 aan te bied met die tema:

\section{DIE VERPLEEGSTUDENT QUO VADIS}

Met hierdie simposium sal aandag aan die volgende aspekte geskenk word:

- huidige stand van die verpleegberoep in Suid-Afrika

- studentewerwing en -keuring en die koste verbonde aan verpleeg-

\section{SIMPOSIUM}

opleiding vir graad- en diplomakursusse

- die problematiek van studentwees - sosialisering van die verpleegstudent in die beroep

- begeleiding van die verpleegstudent tot professionele volwassenheid

\section{Sprekers betrokke:}

- Professore in verpleegkunde, psigologie en publieke administrasie;

- Provinsiale Hoofverplegingsbeampte;

- prinsipale van 'n verpleegkollege; sielkundige en sosioloog;

- geregistreerde en studentverpleegkundiges.

\section{Registrasiefooie:}

Geregistreerde Verpleegkundiges:

Vol:

R20.00

Per dag:

$\mathrm{R} 10,00$

Studentverpleegkundiges:

$\begin{array}{ll}\text { Vol: } & \text { R } 10,00 \\ \text { Per dag: } & \text { R } 5.00\end{array}$

Registrasiefooie sluit tee/koffie en ligte staanmiddagetes en 'n kaas-enwynonthaal in.

Registreer asseblief voor 31 Augustus 1981 by die:

Simposiumsekretaresse.

Departement Verpleegkunde.

Universiteit van Port Elizabeth.

Posbus 1600

PORT ELIZABETH

6000 